\title{
Peningkatan Keaktifan Dan Keterampilan Membaca Teks Piwulang Serat Wulangreh Dengan Model Pembelajaran Kooperatif Tipe Think Pair And Share Pada Siswa Kelas VIII C SMP Negeri 1 Banyudono
}

\author{
Sri Sugiarti \\ SMP Negeri 1 Banyudono \\ Email: sugiartigracia@gmail.com
}

\begin{abstract}
Abstrak: Dalam proses pembelajaran, tentunya ada berbagai masalah yang harus diatasi, antara lain mengenai proses dan hasil pembelajaran yang kurang maksimal. Penelitian ini bertujuan untuk meningkatkan keaktifan dan keterampilan membaca teks piwulang Serat Wulangreh dengan model pembelajaran kooperatif tipe think pair and share. Penelitian ini dilaksanakan mulai bulan Januari sampai Juni 2019, mulai dari persiapan sampai penyusunan laporan. Penelitian ini dilakukan di kelas VIII C SMP Negeri 1 Banyudono tahun pelajaran 2018/2019. Teknik pengumpulan data pada penelitian ini melalui wawancara, observasi, pemberian tes, dan analisis dokumen. Untuk menguji validitas data, peneliti menggunakan triangulasi data dan triangulasi metode. Teknik analisis data dalam penelitian ini yaitu teknik analisis kritis dan deskriptif komparatif. Prosedur penelitian ini menggunakan model kooperatif tipe think pair and share dalam setiap pertemuan. Sedangkan indikator capaian penelitian ini adalah apabila sudah mencapai target yang sudah ditetapkan, dan jumlah siklus ditentukan dari ketercapaian target. Penelitian ini menghasilkan kesimpulan bahwa model kooperatif tipe think pair and share dapat meningkatkan keaktifan dan keterampilan membaca teks piwulang Serat Wulangreh.
\end{abstract}

Kata kunci: Kooperatif, Think Pair And Share, Keaktifan, Keterampilan

\section{PENDAHULUAN}

Salah satu kompetensi dalam kurikulum muatan lokal Bahasa Jawa yang bertujuan untuk memahami nilai-nilai este-tika, etika, moral, kesantunan, dan budi pekerti adalah kompetensi menelaah tembang macapat. Di dalam lirik tembang macapat terdapat piwulang luhur yang dapat diteladani nilai-nilainya dalam kehidupan sehari-hari.

Selama ini dalam pembelajaran tembang macapat lebih ditekankan pada teknik membaca indah dan pengetahuan tentang konsep dari tembang macapat. Padahal di dalam lirik tembang macapat terdapat nilai-nilai pelajaran yang dapat digali dan diterapkan dalam kehidupan sehari-hari sebagai piwulang luhur dari para sastrawan zaman dahulu.

Nilai-nilai dalam tembang macapat sarat akan nilai-nilai kehidupan, penuh makna filosofis, dan identik dengan adat ketimuran, yaitu nilai etika, moral, kesan-tunan, dan budi pekerti. Untuk memahami makna dari suatu tembang macapat diperlukan pemahaman arti dari kata-kata di dalam lirik tembang macapat. Dengan mengasah keterampilan membaca, maka pemahaman pembaca akan semakin terasah. Menurut Somadayo (2011: 10) pengertian membaca pemahaman adalah "Proses pemerolehan makna yang secara aktif melibatkan pengetahuan dan pengala-man yang dimiliki pembaca serta dihu-bungkan dengan isi bacaan."

Dalam kurikulum muatan lokal Bahasa Jawa kelas VIII semester 2 terdapat kompetensi dasar menelaah teks piwulang serat wulangreh pupuh kinanthi. Kompetensi tersebut menuntut siswa untuk dapat memahami makna yang terdapat dalam teks piwulang serat wulangreh pupuh kinanthi. Untuk mengukur ketercapaian suatu kompe-tensi, diperlukan adanya suatu penilaian. Penilaian adalah suatu proses mencari arti atau makna dari data hasil pengukuran didasarkan pada aturan tertentu (Widoyoko, 2014: 4). Diperlukan model pembelajaran yang tepat agar siswa mampu menyerap dengan baik setiap materi pembelajaran yang diajarkan, termasuk materi tentang teks piwulang serat wulangreh pupuh kinanthi.

Model pembelajaran adalah kerangka konseptual tentang prosedur suatu proses 
pembelajaran yang sistematis dan terencana untuk mencapai tujuan pembelajaran secara efektif (Karawati \& Priansa, 2014: 247-248). Pelaksanaan pembelajaran di kelas dapat mengalami permasalahan atau kendala. Salah satunya pada materi teks piwulang serat wulangreh pupuh kinanthi di kelas VIII C SMP Negeri 1 Banyudono. Terdapat $62,5 \%$ siswa yang nilainya masih di bawah KKM. Guru masih menggunakan metode ceramah dalam menyampaikan materi. Sebenarnya metode ceramah boleh digunakan dalam pembelajaran, akan tetapi kurang memacu siswa untuk lebih aktif. Dalam proses pembelajaran materi teks piwulang serat wulangreh pupuh kinanthi di kelas VIII C SMP Negeri 1 Banyudono siswa kurang aktif dan hasil pembelajaran yang didapatkan kurang maksimal.

Berdasarkan permasalahan di atas maka diperlukan solusi pemecahan untuk mengatasinya. Alternatif pembelajaran yang digunakan salah satunya dengan mengubah model pembelajaran. Model pembelajaran yang dirasa efektif untuk meningkatkan keaktifan dan keterampilan membaca pema-haman teks piwulang serat wulangreh adalah model pembelajaran kooperatif tipe think pair and share. Model pembelajaran kooperatif Think Pair and Share (TPS) adalah model pembelajaran yang efektif untuk meningkatkan kegiatan pembelajaran sehingga digunakan lebih banyak waktu untuk belajar (Wardana, Edoh, \& Harwida, 2017: 436). Model pembelajaran ini memungkinkan siswa untuk lebih terlibat aktif dalam kegiatan pembelajaran. Pembelajaran yang baik adalah pembelajaran yang mengutamakan aktivitas siswa, artinya siswa ditempatkan sebagai subjek belajar (Sanjaya, 2006: 135).

$\begin{array}{lrr}\text { Penggunaan } & \text { model } & \text { pembelajaran } \\ \text { tersebut diharapkan } & \text { dapat } & \text { meningkatkan } \\ \text { kemampuan siswa } & \text { dalam } & \text { pembelajaran }\end{array}$ membaca pemahaman teks piwulang serat wulangreh pupuh kinanthi. Model pembelajaran kooperatif tipe think pair and share memungkinkan siswa untuk lebih aktif karena siswa melaksanakan beberapa langkah pembelajaran yang banyak meli-batkan siswa. Jadi siswa tidak hanya mendengarkan penjelasan dari guru, akan tetapi diberi kesempatan untuk berpikir dan melakukan diskusi dengan pasangannya serta memaparkan hasil diskusinya. Baru kemu-dian guru menambah pengetahuan atau konsep yang luput dari perhatian siswa.

Berdasarkan uraian sebelumnya, peneliti tertarik untuk melakukan penelitian dengan judul "Peningkatan Keaktifan dan Keterampilan Membaca Teks Piwulang Serat Wulangreh dengan Model Pembelajaran Kooperatif Tipe Think Pair and Share pada Siswa Kelas VIII C SMP Negeri 1 Banyudono".

\section{METODE PENELITIAN}

Bentuk penelitian ini adalah penelitian tindakan kelas dengan subjek kelas VIII C SMP Negeri 1 Banyudono. Penelitian ini dilakukan pada bulan Januari sampai dengan Juni 2019. Data dan sumber data yang digunakan dalam penelitian ini antara lain silabus, RPP, dan hasil pengamatan di kelas. Pengamatan di kelas ini berupa pengamatan keaktifan dan keterampilan. Teknik pengumpulan data berupa wawan-cara, observasi, pemberian tes dan analisis dokumen. Uji validitas dilakukan dengan cara menggunakan triangulasi data dan metode. Teknik analisis data dalam penelitian ini adalah teknik analisis kritis dan deskriptif komparatif. Sedangkan penelitian ini dikatakan berhasil apabila siswa mencapai Kriteria Ketuntasan Minimal (KKM), yaitu 75. Prosedur penelitian ini terdiri dari tiga tahap, yaitu tahap perencanaan, tindakan atau pelaksanaan, observasi dan evaluasi, serta analisis dan refleksi.

\section{HASIL PENELITIAN DAN PEMBAHASAN Data Pratindakan}

Hasil pengamatan yang dilakukan oleh peneliti pada tahap pratindakan menunjukkan bahwa guru masih mengguna-kan metode ceramah dan tanya jawab dalam kegiatan pembelajaran menelaahteks piwulang serat wulangreh pupuh kinanthi. Guru menyajikan materi dengan mengguna-kan panduan berupa buku ajar atau buku paket yang juga menjadi buku pegangan siswa. Guru juga mencatat materi di papan tulis sambil menerangkan kepada siswa.

Pada pelaksanan pratindakan ini siswa masih terlihat kurang aktif, bahkan ada beberapa siswa yang terlihat mengantuk, terutama siswa 
yang duduk di kursi bagian belakang. Selain itu kemampuan siswa pun masih terlihat rendah, hal itu terlihat ketika siswa diberikan pertanyaan secara lisan maupun tertulis. Ketika siwa diberikan pertanyaan secara lisan banyak siswa yang pasif. Selain itu dari hasil tes evaluasi siswa juga menunjukkan bahwa siswa masih memperoleh nilai yang rendah.

Beberapa penyebab dari permasala-han tersebut adalah karena pembelajaran masih berpusat pada guru, bukan pada siswa, sehingga siswa cenderung pasif dan tidak semangat dalam pembelajaran. Selama proses pembelajaran perhatian guru belum merata dan lebih fokus pada siswa yang duduk di bangku depan, sehingga siswa yang berada di deretan bangku belakang beberapa terlihat mengantuk dan ada juga yang mengobrol dengan temannya.

Perolehan nilai keaktifan siswa dalam proses pembelajaran ditunjukkan dari hasil observasi yang dilakukan oleh peneliti. Adapun tabel distribusi frekuensi keaktifan siswa dalam pembelajaran menelaah teks piwulang serat wulangreh pupuh kinanthi pada siswa kelas VIII C SMP Negeri 1 Banyudonoadalah sebagai berikut:

Tabel 4.1. Distribusi Frekuensi Tingkat Keaktifan Siswa dalam Pembelajaran Menelaah Teks Piwulang Serat Wulangreh Pupuh Kinanthi Pratindakan

\begin{tabular}{|c|c|c|c|}
\hline No. & $\begin{array}{c}\text { Interval } \\
\text { Nilai }\end{array}$ & $\begin{array}{l}\text { Frekuensi } \\
\text { (fi) }\end{array}$ & $\begin{array}{c}\text { Persentase } \\
(\%)\end{array}$ \\
\hline 1. & $10-29$ & 0 & 0 \\
\hline 2. & $30-49$ & 12 & 37,5 \\
\hline 3. & $50-69$ & 16 & 50 \\
\hline 4. & $70-89$ & 3 & 9,375 \\
\hline 5. & $90-100$ & 1 & 3,125 \\
\hline & Jumlah & 32 & 100 \\
\hline
\end{tabular}

Dari tabel 4.1. dapat dilihat bahwa siswa kelas VIII C SMP Negeri 1 Banyudono yang memiliki nilai keaktifan rendah dalam proses pembelajaran menelaah teks piwulang serat wulangreh pupuh kinanthi masih banyak. Berdasarkan hal tersebut maka diperlukan suatu tindakan untuk mengatasi tingkat keaktifan siswa yang masih rendah.

Di samping nilai keaktifan, hasil perhitungan tes evaluasi kemampuan menelaah teks piwulang serat wulangreh pupuh kinanthi pada tahap pratindakan diperoleh nilai rata-rata sebesar 66,25. Untuk informasi yang lebih jelas mengenai nilai keterampilan siswa dalam menelaah teks piwulang serat wulangreh pupuh kinanthi, peneliti sajikan dalam tabel berikut:

Tabel 4.2. Distribusi Frekuensi Nilai Kemampuan Menelaah Teks Piwulang Serat Wulangreh Pupuh Kinanthi Pratindakan

\begin{tabular}{|c|c|c|c|c|}
\hline No & $\begin{array}{c}\text { Interval } \\
\text { Nilai }\end{array}$ & $\begin{array}{c}\text { Frek. } \\
\text { (fi) }\end{array}$ & $\begin{array}{c}\text { Per. } \\
\%\end{array}$ & Ket. \\
\hline 1. & $40-50$ & 8 & 25 & $\begin{array}{l}\text { Belum } \\
\text { Tuntas }\end{array}$ \\
\hline 2. & $51-60$ & 8 & 25 & $\begin{array}{l}\text { Belum } \\
\text { Tuntas }\end{array}$ \\
\hline 3. & $61-70$ & 4 & 12,5 & $\begin{array}{l}\text { Belum } \\
\text { Tuntas }\end{array}$ \\
\hline 4. & 71-80 & 12 & 37,5 & Tuntas \\
\hline 5. & $81-90$ & 0 & 0 & - \\
\hline 6. & $91-100$ & 0 & 0 & - \\
\hline & Jumlah & 32 & 100 & - \\
\hline
\end{tabular}

Nilai Rata-rata $=2120: 32=66,25$

Ketuntasan Klasikal $=12: 32 \times 100 \%=37,5 \%$ Data tersebut menunjukkan bahwa dari 32 siswa hanya 12 siswa yang nilainya memenuhi kriteria keruntasan minimal, atau dengan kata lain ketuntasan klasikalnya sebesar $37,5 \%$.

\section{Deskripsi Hasil Tindakan Setiap Siklus Siklus I}

Materi yang dipelajari adalah menelaah teks piwulang serat wulangreh pupuh kinanthi yaitu meliputi materi tembang macapat, kata sulit, dan memaknai lirik dalam teks piwulang serat wulangreh pupuh kinanthi. Sebelum penjelasan materi, terlebih dahulu guru menjelaskan tahap pelaksanaan pembelajaran menggunakan metode think pair and share. Hal tersebut dilakukan agar siswa paham dan pelaksanaan pembelajaran berjalan dengan baik dan lancar. Pengarahan yang dilakukan berupa langkah-langkah pembelajaran kooperatif think pair and share yang meliputi, menganalisis makna teks piwulang serat wulangreh pupuh kinanthi secara individu, berdiskusi dengan teman sebangku mengenai makna teks piwulang serat wulangreh pupuh kinanthi yang telah dianalisis, dan presentasi hasil diskusi tiap perwakilan kelompok di depan kelas.

Pengarahan tersebut bertujuan agar siswa memperoleh gambaran yang jelas mengenai model pembelajaran kooperatif think 
pair and share. Dengan demikian diharapkan siswa dapat mengikuti kegiatan pembelajaran dengan baik dan melaksanakan pembelajaran tahap demi tahap sesuai prosedur yang telah ditetapkan. Selain itu hal tersebut dilakukan agar siswa lebih antusias dalam pembelajaran karena pembelajaran yang akan dilaksanakan menggunakan metode yang berbeda dengan pembelajaran sebelumnya.

Pada tindakan siklus I diperoleh hasil bahwa nilai rata-rata keaktifan siswa meningkat dibandingkan dengan hasil nilai rata-rata keaktifan siswa pada tahap prasiklus, yaitu dari 56,65 pada saat prasiklus naik menjadi 72,75 pada tahap siklus I ini. Meskipun sudah meningkat, akan tetapi belum mencapai target yang telah ditentukan, yaitu minimal terdapat sejumlah $75 \%$ siswa yang memiliki kriteria keaktifan tinggi. Pada tahap siklus I ini baru sebesar $56,25 \%$ siswa atau sejumlah 18 siswa yang memiliki tingkat keaktifan tinggi. Batas nilai keaktifan dianggap tinggi apabila berada pada interval nilai 70 ke atas.

Tabel 4.3 Distribusi Frekuensi Tingkat Keaktifan Siswa dalam Pembelajaran Menelaah Teks Piwulang Serat Wulangreh Pupuh Kinanthi Siklus I

\begin{tabular}{|c|c|c|c|}
\hline No. & $\begin{array}{c}\text { Interval } \\
\text { Nilai }\end{array}$ & $\begin{array}{l}\text { Frekuensi } \\
\text { (fi) }\end{array}$ & $\begin{array}{c}\text { Persentase } \\
(\%)\end{array}$ \\
\hline 1. & $10-29$ & 0 & 0 \\
\hline 2. & $30-49$ & 3 & 9,375 \\
\hline 3. & $50-69$ & 11 & 34,375 \\
\hline 4. & $70-89$ & 15 & 46,875 \\
\hline \multirow[t]{2}{*}{5.} & $90-100$ & 3 & 9,375 \\
\hline & Jumlah & 32 & 100 \\
\hline
\end{tabular}

Selain nilai keaktifan siswa, diperoleh nilai tes menelaah teks piwulang serat wulangreh pupuh kinanthi dengan hasil yang menunjukkan sejumlah $68,75 \%$ siswa sudah mencapai batas kriteria ketuntasan minimal atau sejumlah 22 siswa tuntas dari total 32 siswa di kelas VIII C SMP Negeri 1 Banyudono. Sementara itu sejumlah 10 siswa atau $31,25 \%$ siswa nilainya masih belum memenuhi kriteria ketuntasan minimal dan masih perlu perbaikan. Untuk informasi yang lebih rinci, peneliti sajikan dalam tabel 4.4. berikut ini:
Tabel 4.4. Distribusi Frekuensi Nilai Kemampuan Menelaah Teks Piwulang Serat Wulangreh Pupuh Kinanthi Siklus I

\begin{tabular}{|c|c|c|c|c|}
\hline No. & $\begin{array}{c}\text { Interval } \\
\text { Nilai } \\
\end{array}$ & $\begin{array}{c}\text { Frek. } \\
\text { (fi) }\end{array}$ & $\begin{array}{l}\text { Per. } \\
(\%)\end{array}$ & Ket. \\
\hline 1. & $40-50$ & 0 & 0 & - \\
\hline 2. & $51-60$ & 4 & 12,5 & Belum Tuntas \\
\hline 3. & $61-70$ & 6 & 18,75 & Belum Tuntas \\
\hline 4. & $71-80$ & 13 & $\begin{array}{c}40,62 \\
5\end{array}$ & Tuntas \\
\hline 5. & $81-90$ & 9 & $\begin{array}{c}28,12 \\
5\end{array}$ & Tuntas \\
\hline 6. & $91-100$ & 0 & 0 & - \\
\hline & Jumlah & 32 & 100 & - \\
\hline \multicolumn{5}{|c|}{ Nilai Rata-rata $=2510: 32=78,43$} \\
\hline
\end{tabular}

Pada tahap pelaksanaan siklus I ini nilai rata-rata yang diperoleh siswa sebesar 78,43 yang meningkat jika dibandingan dengan nilai rata-rata yang diperoleh siswa pada tahap prasiklus yaitu sebesar 66,25. Nilai rata-rata yang diperoleh siswa sudah melampaui batas kriteria ketuntasan minimal yaitu besarnya 75 .

\section{Siklus II}

Pada tahap siklus II materi yang dipelajari adalah materi menelaah teks piwulang serat wulangreh pupuh kinanthi. Sebelumnya guru mengingatkan kepada siswa tentang tahaptahap metode pembela-jaran think pair and share. Hal tersebut dilakukan agar pembelajaran dapat berjalan dengan baik dan lancar. Di awal pembelajaran siswa mendengarkan materi yang disampaikan oleh guru yang menggu-nakan media power point, kemudian guru menyampaikan materi tentang kata sulit yang terdapat dalam teks piwulang serat wulangreh pupuh kinanthi pada 3. Setelah itu baru kemudian pelaksanaan pembelajaran dengan metode think pair and share.

Pada tahap pertama siswa menganalisis secara individu makna dari teks piwulang serat wulangreh pupuh kinanthi pada 3, kemudian dilanjutkan tahap berdis-kusi dengan teman sebangku mengenai hasil analisis yang telah dilakukan secara individu. Setelah itu baru dilanjutkan tahap presentasi perwakilan setiap siswa.

Pada tahap siklus II ini siswa terlihat lebih antusias dalam mengikuti pembela-jaran. Tidak ada lagi siswa yang mengantuk. Pada pertemuan sebelumnya yaitu pada tahap siklus I banyak siswa yang menolak ketika diminta 
untuk tampil maju karena kurangnya kesiapan dan kepercayaan diri siswa, akan tetapi pada siklus II ini para siswa lebih berani dan tidak ragu-ragu untuk maju presentasi. Kemampuan siswa dalam menelaah teks piwulang serat wulangreh pupuh kinanthi pada tahap siklus II ini juga meningkat jika dibandingkan dengan Kemampuan siswa dalam menelaah teks piwulang serat wulangreh pupuh kinanthi pada tahap siklus II siklus I, hal ini terlihat dari hasil tes evaluasi siswa yang nilai rata-ratanya lebih baik.

Pada tabel 4.5. menunjukkan bahwa keaktifan siswa dalam proses pembelajaran menelaah teks piwulang serat wulangreh pupuh kinanthi memperoleh nilai rata-rata sebesar 86,93. Dari hasil nilai tersebut dapat disimpulkan bahwa nilai rata-rata keaktifan siswa dalam pembelajaran menelaah teks piwulang serat wulangreh pupuh kinanthi mengalami peningkatan jika dibandingkan dengan hasil nilai rata-rata pada siklus I yaitu sebesar 72,75. Untuk informasi yang lebih rinci peneliti sajikan dalam bentuk tabel di bawah ini:

Tabel 4.5. Distribusi Frekuensi Tingkat Keaktifan Siswa dalam Pembelajaran Menelaah Teks Piwulang Serat Wulangreh Pupuh Kinanthi Siklus II

\begin{tabular}{|c|c|c|c|}
\hline No. & $\begin{array}{c}\text { Interval } \\
\text { Nilai }\end{array}$ & $\begin{array}{l}\text { Frekuensi } \\
\text { (fi) }\end{array}$ & $\begin{array}{c}\text { Persentase } \\
(\%)\end{array}$ \\
\hline 1. & $10-29$ & 0 & 0 \\
\hline 2. & $30-49$ & 0 & 0 \\
\hline 3. & $50-69$ & 5 & 15,625 \\
\hline 4. & $70-89$ & 17 & 53,125 \\
\hline 5. & $90-100$ & 10 & 31,250 \\
\hline & Jumlah & 32 & 100 \\
\hline
\end{tabular}

Di samping nilai keaktifan siswa dalam proses pembelajaran, diperoleh nilai hasil tes keterampilan menelaah teks piwulang serat wulangreh pupuh kinanthi pada tahap siklus II ini. Hasilnya menunjukkan bahwa jumlah ketuntasan klasikal siswa sebesar 90,62\% atau sejumlah 29 siswa yang nilainya memenuhi kriteria ketuntasan minimal dari jumlah total 32 siswa yang ada di kelas. Sementara itu, sejumlah 3 siswa lainnya atau sebesar 9,37\% siswa belum mencapai kriteria ketuntasan minimal dan masih perlu perbaikan.
Nilai rata-rata keterampilan siswa pada tahap siklus II ini yaitu sebesar 87,18. Hal itu berarti hasil nilai rata-rata keterampilan siswa dalam menelaah teks piwulang serat wulangreh pupuh kinanthi pada tahap siklus II ini mengalami peningkatan jika dibandingkan dengan hasil nilai rata-rata keterampilan siswa pada tahap siklus I yaitu sebesar 78,43 . Untuk informasi yang lebih rinci mengenai hasil penilaian keterampilan menelaah teks piwulang serat wulangreh pupuh kinanthi peneliti sajikan dalam tabel berikut ini:

Tabel 4.6. Distribusi Frekuensi Nilai Kemampuan Menelaah Teks Piwulang Serat Wulangreh Pupuh Kinanthi Siklus II

\begin{tabular}{|c|c|c|c|c|}
\hline No. & $\begin{array}{c}\text { Interval } \\
\text { Nilai }\end{array}$ & $\begin{array}{c}\text { Frek. } \\
\text { (fi) }\end{array}$ & $\begin{array}{l}\text { Per. } \\
(\%)\end{array}$ & Ket. \\
\hline 1. & $40-50$ & 0 & 0 & - \\
\hline 2. & $51-60$ & 0 & 0 & - \\
\hline 3. & $61-70$ & 3 & 9,375 & Belum Tuntas \\
\hline 4. & $71-80$ & 9 & 28,125 & Tuntas \\
\hline 5. & $81-90$ & 8 & 25 & Tuntas \\
\hline 6. & $91-100$ & 12 & 37,5 & Tuntas \\
\hline & Jumlah & 32 & 100 & - \\
\hline \multicolumn{5}{|c|}{ Nilai Rata-rata $=2790: 32=87,18$} \\
\hline
\end{tabular}

Data dalam bentuk tabel tersebut menunjukkan hasil belajar siswa pada tahap siklus II. Hasil nilai tersebut mengalami peningkatan jika dibandingkan dengan hasil nilai siswa pada tahap siklus I. Peningkatan tersebut meliputi peningkatan pada hasil nilai rata-rata siswa dan peningkatan pada jumlah ketuntasan klasikal siswa.

\section{Perbandingan Hasil Tindakan}

a. Keaktifan Siswa dalam Menelaah Teks Piwulang Serat Wulangreh Pupuh Kinanthi

Keaktifan siswa diamati oleh observer yaitu peneliti pada saat proses pembelajaran di kelas sedang berlangsung. Pengamatan tersebut dilakukan dengan mengacu pada lembar observasi yang telah disusun sebelumnya. Hasil peningkatan keaktifan siswa dalam proses pembelajaran menelaah teks piwulang serat wulangreh pupuh kinanthi dengan model pembelajaran koope-ratif think pair and share di kelas VIII C SMP Negeri 1 Banyudono pada tahap prasiklus, siklus I, dan siklus II dapat dilihat pada tabel berikut ini: 
Tabel 4.7. Perbandingan Distribusi Frekuensi Tingkat Keaktifan Siswa dalam Pembelajaran Menelaah Teks Piwulang Serat Wulangreh Pupuh Kinanthi Kelas VIII C pada Prasiklus, Siklus, dan Siklus II

\begin{tabular}{|c|c|c|c|c|}
\hline \multirow{2}{*}{ No. } & \multirow{2}{*}{$\begin{array}{c}\text { Interval } \\
\text { Nilai }\end{array}$} & \multicolumn{3}{|c|}{ Frekuensi (fi) } \\
\cline { 3 - 5 } & $10-29$ & 0 & 0 & 0 \\
\hline 1. & Prasiklus & $\begin{array}{c}\text { Siklus } \\
\text { I }\end{array}$ & $\begin{array}{c}\text { Siklus } \\
\text { II }\end{array}$ \\
\hline 2. & $30-49$ & 12 & 3 & 0 \\
\hline 3. & $50-69$ & 16 & 11 & 5 \\
\hline 4. & $70-89$ & 3 & 15 & 17 \\
\hline 5. & $90-100$ & 1 & 3 & 10 \\
\hline & $\begin{array}{c}\text { Nilai } \\
\text { rata- } \\
\text { rata }\end{array}$ & $\mathbf{5 6 , 6 5}$ & $\mathbf{7 2 , 7 5}$ & $\mathbf{8 6 , 9 3}$ \\
\hline
\end{tabular}

Berdasarkan data pada tabel 4.7. diperoleh informasi bahwa hasil observasi yang dilakukan oleh peneliti mengenai keaktifan siswa selama proses pembelajaran menelaah teks piwulang serat wulangreh pupuh kinanthi pada tahap prasiklus nilai rata-ratanya sebesar 56,65, pada tahap siklus I sebesar 72,75 , dan pada tahap siklus II sebesar 86,93 . Peningkatan nilai keaktifan siswa dari tahap prasiklus, siklus I, dan siklus II jika disajikan dalam bentuk grafik hasilnya sebagai berikut:

b. Keterampilan Menelaah Teks Piwulang Serat Wulangreh Pupuh Kinanthi

Berdasarkan pada hasil tes evaluasi yang telah dikerjakan oleh siswa pada setiap akhir sesi pembelajaran baik tahap prasiklus, siklus I, dan siklus II diperoleh kesimpulan bahwa terdapat peningkatan keterampilan menelaah teks piwulang serat wulangreh pupuh kinanthi pada siswa kelas VIII C SMP Negeri 1 Banyudono. Hal tersebut terbukti dari meningkatnya nilai rata-rata yang diperoleh siswa pada setiap siklus yaitu pada tahap prasiklus nilai rata-rata yang diperoleh siswa sebesar 66,25, pada tahap siklus I sebesar 78,43, dan pada tahap siklus II sebesar 87,18.

Selain nilai rata-rata siswa yang meningkat, peningkatan keterampilan siswa dalam menelaah teks piwulang serat wulangreh pupuh kinanthi juga terbukti dari hasil persentase ketuntasan klasikal siswa yang selalu mengalami kenaikan di setiap siklusnya, yaitu pada tahap prasiklus persentase ketuntasan klasikal yang diperoleh siswa sebesar 37,5\%, naik pada siklus I menjadi $68,75 \%$, dan pada siklus II menjadi 90,62\%. Peningkatan keterampilan menelaah teks piwulang serat wulangreh pupuh kinanthi dengan model pembelajaran koope-ratif think pair and share pada siswa kelas VIII C SMP Negeri 1 Banyudono dari tahap prasiklus, siklus I, dan siklus II dapat dilihat pada tabel berikut ini:

Tabel 4.8. Perbandingan Data Frekuensi Nilai Keterampilan Siswa dalam Menelaah Teks Piwulang Serat Wulangreh Pupuh Kinanthi Kelas VIII C pada Pratindakan, Siklus, dan Siklus II

\begin{tabular}{|c|l|c|c|c|}
\hline No. & Keterangan & $\begin{array}{c}\text { Pra } \\
\text { siklus }\end{array}$ & $\begin{array}{c}\text { Siklus } \\
\text { I }\end{array}$ & $\begin{array}{c}\text { Siklus } \\
\text { II }\end{array}$ \\
\hline 1. & $\begin{array}{l}\text { Nilai rata-rata } \\
\text { klasikal }\end{array}$ & 66,25 & 78,43 & 87,18 \\
\hline 2. & Nilai tertinggi & 80 & 90 & 95 \\
\hline 3. & Nilai terendah & 50 & 60 & 70 \\
\hline 4. & $\begin{array}{l}\text { Persentase } \\
\text { ketuntasan } \\
\text { klasikal }\end{array}$ & $37,5 \%$ & $\begin{array}{c}68,75 \\
\%\end{array}$ & $\begin{array}{c}90,62 \\
\%\end{array}$ \\
\hline
\end{tabular}

Dari tabel tersebut terlihat bahwa nilai yang diperoleh siswa selalu mengalami kenaikan pada setiap siklus.

Berdasarkan pada tabel 4.8. dan gambar 4.5. diperoleh informasi berupa per-bandingan daftar frekuensi nilai keterampilan menelaah teks piwulang serat wulangreh pupuh kinanthi pada tahap prasiklus, siklus I, dan siklus II. Berikut ini penjelasan yang lebih rinci:

1) Pada pratindakan terdapat 8 siswa yang mendapat nilai antara 40-50, sedangkan pada siklus I tidak terdapat siswa yang mendapat nilai antara 40-50, dan pada siklus II tidak terdapat siswa yang mendapat nilai antara 40-50.

2) Pada pratindakan terdapat 8 siswa yang mendapat nilai antara 51-60, sedangkan pada siklus I terdapat 4 siswa yang mendapat nilai antara 51-60, dan pada siklus II tidak terdapat siswa yang mendapat nilai antara 51-60.

3) Pada pratindakan terdapat 4 siswa yang mendapat nilai antara 61-70, sedangkan pada siklus I terdapat 6 siswa yang mendapat nilai antara 61-70, dan pada siklus II terdapat 3 siswa yang mendapat nilai antara 61-70.

4) Pada pratindakan terdapat 12 siswa yang mendapat nilai antara 71-80, sedangkan 
pada siklus I terdapat 13 siswa yang mendapat nilai antara 71-80, dan pada siklus II terdapat 9 siswa yang mendapat nilai antara 71-80.

5) Pada pratindakan tidak terdapat siswa yang mendapat nilai antara 81-90, sedangkan pada siklus I terdapat 9 siswa yang mendapat nilai antara 81-90, dan pada siklus II terdapat 8 siswa yang mendapat nilai antara 81-90.

6) Pada pratindakan tidak terdapat siswa yang mendapat nilai antara 91-100, pada siklus I juga tidak terdapat siswa yang mendapat nilai antara 91-100, dan pada siklus II terdapat 12 siswa yang mendapat nilai antara 91-100.

Berdasarkan pada data nilai keterampilan menelaah teks piwulang serat wulangreh pupuh kinanthi yang diperoleh dari hasil tes evaluasi siswa pada setiap akhir sesi pembelajaran, banyaknya siswa yang memperoleh nilai di atas 75 (KKM) mengalami peningkatan yang signifikan di setiap siklusnya, yaitu perolehannya sebesar $37,5 \%$ pada prasiklus, meningkat menjadi $68,75 \%$ pada siklus I, dan meningkat lagi menjadi $90,62 \%$ pada siklus II. Dari hasil tersebut dapat direfleksikan adanya keberhasilan dari penerapan model pembelajaran kooperatif think pair and share pada siswa kelas VIII C SMP Negeri 1 Banyudono tahun pelajaran 2018/2019, karena nilai keterampilan menelaah teks piwulang serat wulangreh pupuh kinanthi secara klasikal menunjukkan adanya peningkatan.

Berdasarkan data diperoleh informasi mengenai meningkatnya nilai keterampilan siswa dalam menelaah teks piwulang serat wulangreh pupuh kinanthi kelas VIII C SMP Negeri 1 Banyudono yaitu pada interval nilai 91-100. Berdasarkan pada hasil wawancara peneliti dengan siswa dan guru sebelum dan sesudah dilaksanakannya tindakan, hasil observasi yang dilakukan peneliti pada saat proses pembelajaran menelaah teks piwulang serat wulangreh pupuh kinanthi berlangsung, dan hasil nilai tes evaluasi keterampilan menelaah teks piwulang serat wulangreh pupuh kinanthi, maka hasilnya dapat dibuat dalam bentuk tabel rekapitulasi pratindakan, siklus I, dan siklus II berikut ini:
Tabel 4.9. Rekapitulasi Pratindakan, Siklus I, dan Siklus II

\begin{tabular}{|c|c|c|c|}
\hline $\begin{array}{c}\text { Pembelajaran } \\
\text { Bahasa Jawa Materi } \\
\text { Menelaah Teks } \\
\text { Piwulang Serat } \\
\text { Wulangreh Pupuh } \\
\text { Kinanthi }\end{array}$ & $\begin{array}{c}\text { Pra } \\
\text { tindakan }\end{array}$ & Siklus I & Siklus II \\
\hline $\begin{array}{l}\text { Pelaksanaan } \\
\text { pembelajaran }\end{array}$ & $\begin{array}{l}\text { Ceramah, } \\
\text { berpusat } \\
\text { pada guru, } \\
\text { kurang } \\
\text { melibatkan } \\
\text { siswa } \\
\text { secara } \\
\text { aktif }\end{array}$ & $\begin{array}{l}\text { Penerap } \\
\text { an } \\
\text { model } \\
\text { pembel } \\
\text { ajaran } \\
\text { koopera } \\
\text { tif } \text { think } \\
\text { pair } \\
\text { and } \\
\text { share }\end{array}$ & $\begin{array}{l}\text { Penerapa } \\
\mathrm{n} \text { model } \\
\text { pembelaj } \\
\text { aran } \\
\text { kooperati } \\
\mathrm{f} \text { think } \\
\text { pair and } \\
\text { share }\end{array}$ \\
\hline $\begin{array}{l}\text { Jumlah siswa } \\
\text { mencapai KKM }\end{array}$ & 12 & 22 & 29 \\
\hline Nilai rata-rata & 66,25 & 78,43 & 87,18 \\
\hline Persentase ketuntasan & $37,5 \%$ & $68,75 \%$ & $90,62 \%$ \\
\hline
\end{tabular}

Berdasarkan pada tabel tersebut terlihat bahwa selalu terdapat peningkatan pada jumlah siswa yang hasil nilainya dalam pembelajaran mencapai kriteria ketuntasan minimal, selain itu juga selalu terdapat peningkatan hasil nilai ratarata siswa dan persentase ketuntasan siswa di setiap siklusnya. Berdasarkan pada tabel 4.9. rekapitulasi nilai rata-rata dan persentase ketuntasan nilai menelaah teks piwulang serat wulangreh pupuh kinanthi pratindakan, siklus I, dan siklus II apabila digambarkan dalam bentuk grafik sebagai berikut: 

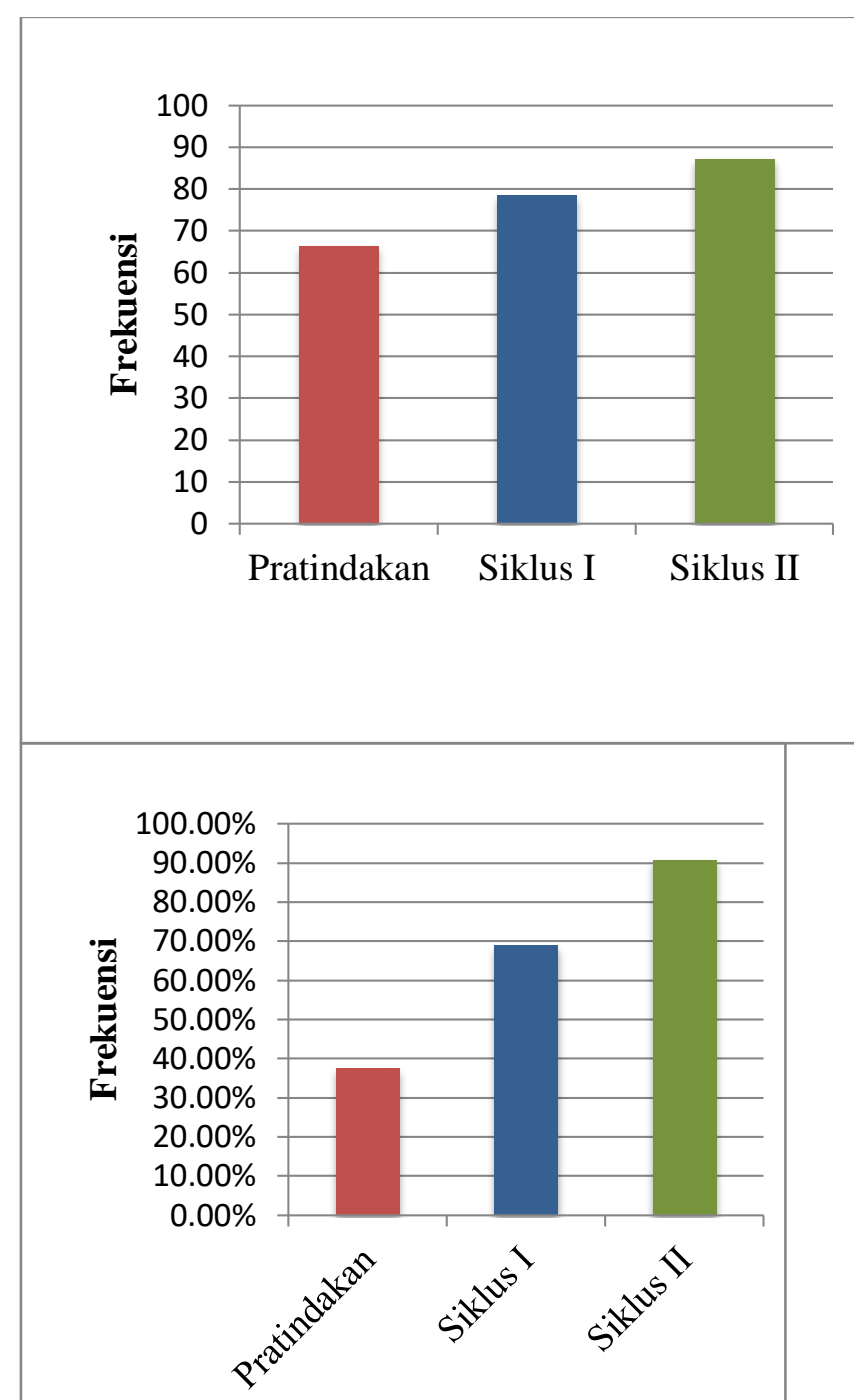

\section{Gambar 4.6. Rekapitulasi Pratindakan, Siklus I, dan Siklus II}

Berdasarkan pada gambar 4.6. dapat dinyatakan bahwa hasil nilai pembelajaran menelaah teks piwulang serat wulangreh pupuh kinanthi dengan model pembelajaran kooperatif think pair and share pada siswa kelas VIII C SMP Negeri 1 Banyudono mengalami peningkatan. Nilai rata-rata yang diperoleh siswa pada pratindakan sebesar 66,25, setelah adanya tindakan siklus I meningkat menjadi 78,43, dan setelah tindakan siklus II meningkat kembali menjadi 87,18. Untuk frekuensi ketuntasan siswa juga mengalami peningkatan, pada tahap prasiklus terdapat sejumlah 12 siswa atau sebesar $37,5 \%$ siswa yang tuntas, pada tahap siklus I meningkat menjadi 22 siswa atau sebesar $68,75 \%$ siswa yang tuntas, dan pada tahap siklus II naik menjadi 29 siswa atau sebesar 90,62\% siswa yang tuntas.

\section{SIMPULAN}

Berdasarkan pada hasil penelitian tindakan yang dilaksanakan di kelas VIII C SMP Negeri 1 Banyudono mengenai pembelajaran menelaah teks piwulang serat wulangreh pupuh kinanthi dengan menggunakan model pembelajaran koope-ratif think pair and share diperoleh kesimpulan bahwa:

1. Penerapan model pembelajaran kooperatif think pair and share dapat meningkatkan kualitas proses pembelajaran menelaah teks piwulang serat wulangreh pupuh kinanthi pada siswa kelas VIII C SMP Negeri 1 Banyudono tahun pelajaran 2018/2019.

2. Penerapan model pembelajaran kooperatif think pair and share dapat meningkatkan kualitas hasil pembela-jaran menelaah teks piwulang serat wulangreh pupuh kinanthi pada siswa kelas VIII C SMP Negeri 1 Banyudono tahun pelajaran 2018/2019.

\section{Implikasi}

\section{Implikasi Teoretis}

Berdasarakan pada hasil penelitian tindakan kelas yang telah dilakukan menunjukkan bahwa pene-rapan model pembelajaran koope-ratif think pair and share dapat meningkatkan tingkat keaktifan dan nilai keterampilan siswa dalam menelaah teks piwulang serat wulangreh pupuh kinanthi di kelas VIII C SMP Negeri 1 Banyudono yang ditinjau dari beberapa hal berikut:

a. Penerapan model pembelajaran kooperatif think pair and share berpengaruh pada tingkat keaktifan siswa. Siswa yang awalnya pasif ketika pembelajaran menjadi lebih aktif setelah model pembelajaran kooperatif think pair and share diterapkan. Hal tersebut karena model pembelajaran ini berpusat pada siswa. Tingkat keaktifan siswa yang tinggi berpengaruh pada hasil nilai belajar siswa yang tinggi.

b. Penerapan model pembelajaran ini membuat siswa lebih antusias dalam pembelajaran. Siswa cenderung tidak bosan ketika mengikuti pembelajaran karena tahap pembelajaran lebih variatif. 
2. Implikasi Praktis

a. Penelitian tindakan kelas ini dapat dikembangkan oleh guru dalam menghadapi permasalahan pembelajaran yang sejenis.

b. Dapat digunakan sebagai bahan acuan pada penggunaan model pembelajaran kooperatif think pair and share.

c. Sebagai penambah wawasan bagi guru untuk meningkatkan keterampi-lan menelaah teks piwulang serat wulangreh pupuh kinanthi dengan model pembelajaran kooperatif think pair and share.

\section{SARAN}

Berdasarkan pada simpulan dan implikasi hasil penelitian, ada beberapa saran yang disampaikan dalam rangka meningkat-kan mutu pendidikan. Saran-saran yang disampaikan di antaranya:

1. Bagi Siswa

a. Siswa sebaiknya mengikuti tahap demi tahap pembelajaran dengan disiplin sehingga waktu yang diguna-kan dalam pembelajaran menjadi lebih efektif.

b. Siswa sebaiknya lebih meningkatkan kerjasamanya dalam kelompok untuk memecahkan masalah.

c. Siswa hendaknya mengaplikasikan ilmu yang diperoleh dalam kehidupan seharihari, baik dalam lingkungan sekolah maupun lingkungan keluarga dan masyarakat.

2. Bagi Guru

a. Guru sebaiknya menerapkan model pembelajaran kooperatif think pair and share dalam pembelajaran menelaah teks piwulang serat wulangreh pupuh kinanthi dan pada materi pembelajaran lain yang cocok menggunakan model pembelajaran ini.

b. Guru sebaiknya menambah wawasan mengenai variasi model-model pembelajaran dan menerapkannya di kelas agar siswa tidak bosan dan lebih semangat mengikuti pembelajaran. Selain itu, hal yang paling penting adalah model pembelajaran yang diterapkan sebaiknya yang dapat mengatasi permasalahan yang ada di kelas.

c. Guru sebaiknya mengenal lebih dekat karakter siswanya, agar dalam mengajar guru dapat menstimulus dan meningkatkan kemampuan setiap siswa dengan cara yang tepat.

3. Bagi Sekolah

a. Sekolah sebaiknya mendukung penerapan model pembelajaran yang kreatif seperti model pembelajaran kooperatif think pair and share dalam pembelajaran menelaah teks piwulang serat wulangreh pupuh kinanthi.

b. Sekolah sebaiknya memberikan fasilitas yang memadai dalam rangka meningkatkan kualitas pembelajaran di kelas.

c. Sekolah hendaknya memantau dan memperhatikan secara kontinu kemajuan hasil belajar peserta didik.

4. Bagi Peneliti Lain

a. Dapat digunakan sebagai bahan acuan bagi peneliti lain untuk menerapkan model pembelajaran yang sama disesuaikan dengan materi pembelajaran yang cocok.

b. Peneliti lain dapat mengembangkan model pembelajaran think pair share agar lebih menarik dan menye-nangkan bagi siswa, baik dalam mata pelajaran Bahasa Jawa maupun mata pelajaran yang lain

\section{DAFTAR PUSTAKA}

Karawati, Euis, \& Priansa, Donni Juni. (2014). Manajemen Kelas (Classroom Management) Guru Profesional yang Inspiratif, Kreatif, Menyenangkan, dan Berprestasi. Bandung: Penerbit Alfabeta.

Sanjaya, Wina. (2006). Strategi Pembelajaran. Jakarta: Kencana Prenadamedia Group.

Somadayo, Samsu. (2011). Strategi dan Teknik Pembelajaran Membaca. Yogyakarta: Graha Ilmu.

Wardana, Ludi Wishnu, Edoh, \& Gleydis Harwida. (2017). Implementation of Collaborative Learning Model Thinking Pair Share (TPS) and Arias to Improve Student Learning Result in 
Entrepreneurship Subjects.

International Journal of Academic Research in Business and Social Sciences, 7 (7), 435-444. Diperoleh pada 15 Maret 2019, dari http://hrmars.com/hrmars_papers/Imple mentation_Of_Collaborative_Learning _Model_Thinking_Pair_Share_(TPS)_ And_Arias_To_Improve_Student_Lear ning_Results_In_Entrepreneurship_Su bjects.pdf.

Widoyoko, Eko Putro. (2014). Penilaian Hasil Pembelajaran Di Sekolah. Yogyakarta: Pustaka Pelajar. 